\title{
Struktur kalimat interogatif bahasa Jawa pada film “Tilik” karya Wahyu Agung Prasetyo: Analisis X-Bar
}

\section{Habib Rois ${ }^{I^{*}}$, Regita Sekar Arrum², Jemima Jannah Darla Putri ${ }^{3}$, Sumarlam ${ }^{4}$}

Fakultas Ilmu Budaya, Universtas Sebelas Maret J1. Ir. Sutami No.36, Kentingan, Kec. Jebres, Kota Surakarta, Indonesia 'habibrois@student.uns.ac.id, regitasekara@student.uns.ac.id², jemimajdp@student.uns.ac.id ${ }^{3}$,sumarlam@staff.uns.ac.id ${ }^{4}$

*Corresponding author: habibrois@student.uns.ac.id

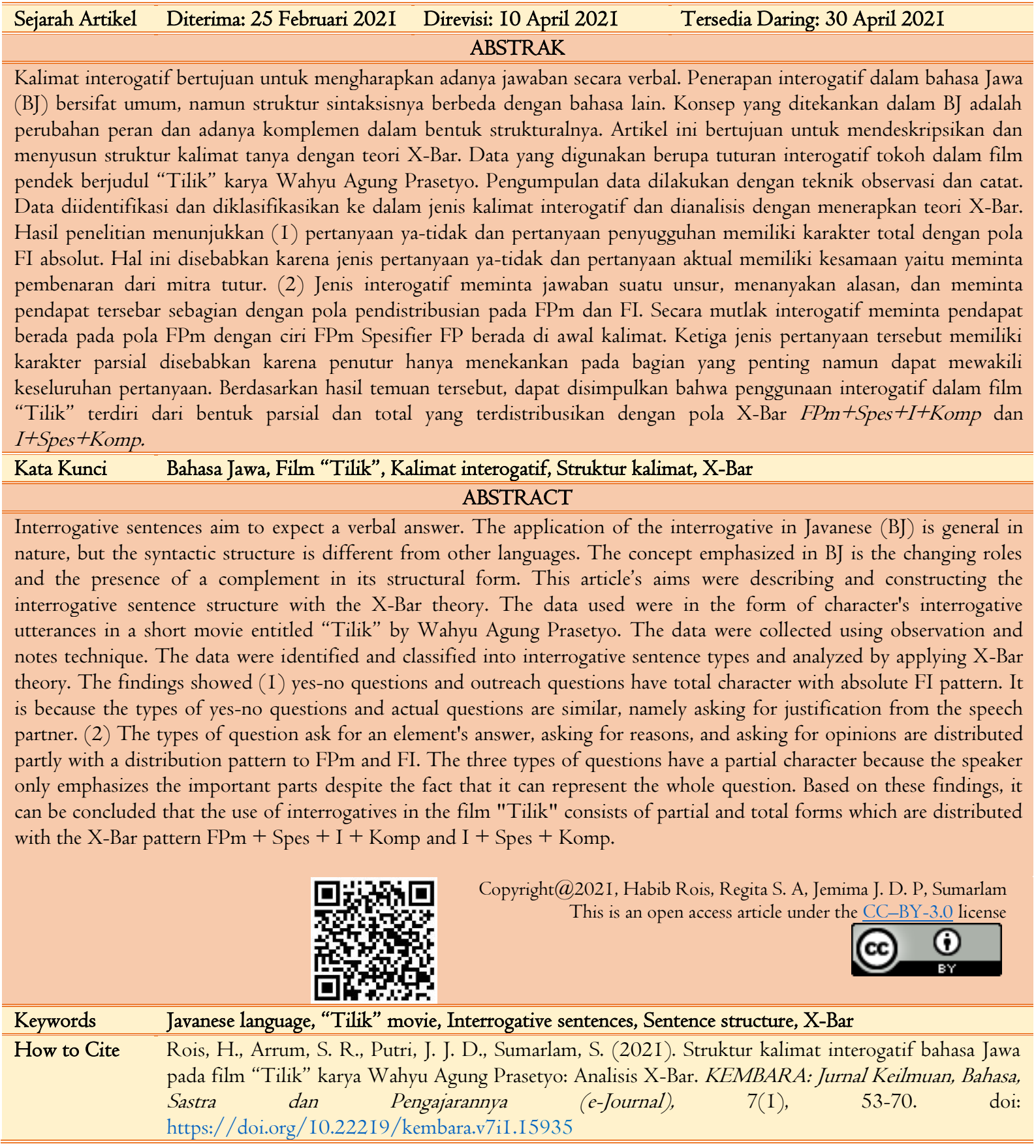




\section{PENDAHULUAN}

Jenis kalimat dalam bahasa Indonesia terdiri atas berbagai macam, salah satunya adalah kalimat interogatif. Secara khusus, kalimat interogatif pun memiliki berbagai jenis. Berdasarkan tujuannya, interogatif dibagi menjadi lima jenis, yaitu interogatif pengakuan ya-tidak, interogatif meminta jawaban mengenai suatu unsur, interogatif alasan, interogatif pendapat, dan interogatif penyungguhan (Chaer, 2015; Gallego \& Martin, 2018). Secara struktural, kalimat interogatif ditandai dengan hadirnya bentuk pronomina berupa kata tanya apa, siapa, di mana, kapan, bagaimana, dan mengapa. Penggunaan kata tanya ini memiliki penerapan yang berbeda dalam setiap bahasa. Perbedaan ini diakibatkan oleh adanya konstruksi kategori, fungsi, dan peran yang berbeda dalam setiap bahasa (Astuti, 20I7; Brown \& Miller, 2015; Crystal, 2017; Isnaini, 2015; Radford, 2000).

Berdasarkan tujuannya, jenis interogatif pada setiap bahasa bersifat sama (Eriyanti, 2017). Lebih jelas, tujuan utama dari interogatif adalah mengharapkan adanya jawaban secara verbal (Pandean, 2018; Wahyuni, 2000). Penerapan interogatif dalam Bahasa Jawa (BJ) bersifat umum, namun secara struktur sintaksisnya memiliki perbedaan dengan bahasa lainnya. Interogatif dalam bentuk komunikasi BJ umumnya menggunakan kata interjeksi seperti Iho, kha, ya, wo, we, wah, adhuh, wadhuh gandrik, ayak, hore, hayo, dan iyung (Mulyono, 201I). Hadirnya model-model interjeksi dan pelengkap lainnya dalam interogatif BJ menjadikan bentuk strukturnya saling berubah peran. Perubahan ini dikarenakan dalam BJ memiliki banyak bentuk kata yang berperan sebagai pelengkap dalam satuan kalimat interogatif. Konsep yang perlu ditekankan dalam perubahan peran dan hadirnya pelengkap dalam interogatif BJ adalah dengan mencari bentuk strukturalnya. Berkaitan dengan struktur kalimat, teori XBar dapat memberikan proyeksi yang cukup jelas untuk mendeskripsikan setiap kasus kebahasaan, khususnya berkaitan dengan struktur sintaksisnya.

Teori X-Bar pertama kali dikembangkan oleh Noam Chomsky pada tahun 50-an atas dasar bentuk pengembangan sebuah frasa (Mulyadi, 20I0). Salah satu pandangan yang terdapat dalam teori X-Bar adalah bahwa semua frasa memiliki inti leksikal yang bervariasi. Bentuk X-Bar memiliki tataran proyeksi, yaitu: (I) jika sebuah kategori leksikal dibentuk oleh komplemen, keterangan, dan spesifier, komplemen yang berkombinasi dengan X-Bar akan membentuk proyeksi lebih tinggi; (2) proyeksi maksimal frasa $\mathrm{X}$ dapat dibentuk dengan cara spesifier berkombinasi dengan $\mathrm{X}$-Bar yang lebih tinggi. Kedua proyeksi tersebut dapat disimbolkan sebagai berikut.

(i)

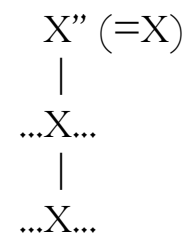

(ii)
a. X"
$\rightarrow \mathrm{YP} ; \mathrm{X}^{\prime}$
b. $X^{\prime} \rightarrow X^{\prime} ; Z P$
[YP : Spesifier]
$[\mathrm{ZP}:$ Keterangan $]$
c. $X^{\prime}$
$\rightarrow \mathrm{X} ; \mathrm{WP}$
[WP : Komplemen]

[Simbol X : leksikal N, V,A, atau P]

Teori X-Bar pada mulanya hanya mengkaji struktur frasa, semakin diperluas penerapannya pada tataran klausa dan kalimat (Haegeman, 2006; Pujiono, 2014). Penelitian Haegeman (2006) dan Pujiono (20I4) memberikan sebuah gambaran mengenai analisis sintaksis menggunakan teori X-Bar. Kedua penelitian tersebut menguraikan proses pembentukan sebuah frasa berdasarkan kelas kata yang bergabung dan peran daripada frasa tersebut. Lebih jelas, kedua penelitian tersebut memperkuat bahwa teori X-Bar mampu memberikan alasan-alasan logis terkait perpindahan dan perubahan kelas kata pada sebuah frasa. Penerapan teori X-Bar ini lebih jauh dapat diaplikasikan ke dalam sebuah kalimat. Artinya, struktur kalimat dikaji secara mendasar melalui kelas kata dan bentuk frasa yang membentuknya.

Secara holistik sebuah kalimat interogatif memiliki konstruksi yang bersifat unik atau dapat dikatakan bahwa setiap kontruksi merepresentasikan modus atau sifat tertentu (Caesar, 2016; Cox, 2020; Lindawati, 2017; Lohmann \& Conwell, 2020; Nikmah, 2020; Siemund, 2017). Ketiga penelitian 
tersebut menguraikan mengenai bentuk-bentuk interogatif serta sifat yang melekat pada model interogatif seperti: alternatif, afirmatif, dan negatif. Bentuk interogatif pada penelitian tersebut difokuskan pada penggunaan bentuk interogatif dan perbedaannya dalam setiap bahasa. Namun, penelitian tersebut belum menganalisis jenis interogatif secara spesifik yang meliputi interogatif pengakuan ya-tidak, interogatif meminta jawaban mengenai suatu unsur, interogatif alasan, interogatif pendapat, dan interogatif penyungguhan. Selain itu, kajian sebelumnya belum membahas penggunaan kalimat interogatif dalam tuturan. Dengan begitu, penelitian ini dapat menunjukkan hasil secara lebih terperinci terhadap penggunaan lima jenis interogatif yang terdapat dalam tuturan bahasa Jawa. Berdasarkan review tersebut, muncul gap penelitian yang meliputi: (I) analisis perubahan kelas kata setiap frasa dalam interogatif memerlukan penurunan yang bersifat logis, (2) analisis struktur gramatikal berdasarkan teori X-Bar dapat digunakan dalam mencari perubahan dan struktur kalimat interogatif.

Penerapan teori X-Bar dalam penelitian ini digunakan untuk menganalisis kalimat interogatif dalam film "Tilik" karya Wahyu Agung Prasetyo. Film "Tilik" merupakan film pendek yang menggunakan komunikasi dengan bahasa Jawa. Bahasa Jawa dalam film "Tilik" memiliki ciri khas yang ditandai dengan adegan gibah. Secara keseluruhan, isi dalam film ini adalah membicarakan keburukan orang lain atau disebut dengan gibah. Secara kebahasaan, adegan gibah ini menggambarkan sebuah penerapan kalimat tanya dengan tujuan untuk mencari informasi tentang keburukan seseorang yang dijadikan target gibah. Penggunaan kalimat tanya dalam film "Tilik" cukup beragam dan memiliki jumlah yang cukup banyak. Artinya, pemilihan film ini didasarkan pada kevariasian bentuk dan ketersediaan kalimat interogatif dalam film "Tilik".

Penerapan teori X-Bar dalam tataran kalimat memiliki kevariasian yang cukup beragam. Bentuk interogatif dalam bahasa tulis seperti dalam novel maupun buku bacaan sejenisnya memiliki tipe yang cenderung ke arah formal maupun nonformal. Budiman \& Mulyadi (2020) menegaskan hal tersebut bahwa penerapan X-Bar dapat diproyeksikan ke dalam bahasa tulis maupun lisan. Namun, tipe pembeda dalam bahasa tulis seperti dalam novel maupun buku bacaan yang berisi dialog direpresentasikan melalui struktur kalimat dan frasa atau klausa pembentuknya. Penerapan X-Bar secara khusus dapat diimplementasikan dalam fenomena bahasa baik secara tulis maupun lisan, di mana setiap satuan kalimat memiliki proyeksi yang cukup jelas. (Morley, 2004; Muller, 2018) menegaskan bahwa, teori XBar dapat digunakan pada tataran kalimat yang memiliki struktur pembentuk frasa maupun klausa yang cukup. Berlandaskan uraian tersebut, penelitian ini mengambil data dalam film guna untuk menerapkan teori X-Bar pada struktur kalimat dan juga mendeskripsikan tipe-tipe kalimat interogatif pada tataran lisan. Penelitian ini lebih ke tingkat pengembangan dari penelitian Budiman \& Mulyadi (2020) yang memfokuskan pada sumber tertulis dan dikembangkan ke dalam sumber bahasa lisan.

Berdasarkan gap dan keberagaman bentuk kalimat interogatif dalam film "Tilik", maka penelitian ini bertujuan untuk mendeskripsikan dan mengkonstruksikan struktur kalimat interogatif bahasa Jawa yang dikaji melalui teori X-Bar guna melihat unsur pembentuk kalimat interogatif dalam setiap variasinya. Bentuk analisis dalam penelitian ini mengacu pada penerapan teori X-Bar, sehingga penelitian ini memfokuskan pada struktur sintaksisnya bukan pada maksud dan tujuan dari setiap jenis kalimat interogatif tersebut. Lebih lanjut, penelitian ini mendeskripsikan terkait pola kalimat interogatif pada bahasa lisan dalam percakapan secara langsung, di mana acuan penelitian sebelumnya oleh Budiman \& Mulyadi (2020) mengacu pada bahasa tulis. Penelitian ini memberikan gambaran khusus mengenai struktur kalimat interogatif dalam bahasa Jawa dilihat dari frasa pembentuknya yang dibedakan dalam frasa infleksi (FI) dan frasa pemerlengkap (FPm).

Struktur kalimat interogatif dalam bahasa Jawa umumnya secara lisan dapat diproyeksikan melalui intonasi, namun ketika ditranskripsikan ke dalam susunan kalimat memiliki pola yang cukup ambigu. Seperti pada kalimat "Dadi aku to seng kleru bu" (Jadi aku yang salah bu), jika dilihat pada kalimat yang diartikan ke dalam bahasa Indonesia, dapat diklasifikasikan ke dalam deklaratif tentang informasi pengakuan. Akan tetapi, berbeda dengan bahasa Jawa yang dimarkahi dengan to di mana jika tanpa penulisan tanda tanya (?) sudah dapat diklasifikasikan ke dalam interogatif. Kasus tersebut jelas 
hanya mengacu pada struktur yang bersifat tekstual beserta tanda baca yang mengikutinya, sehingga memerlukan analisis yang lebih mendalam pada tataran unsur pembentuknya. Berkaitan dengan gap penelitian yang dipaparkan di atas, penelitian ini dapat memberikan uraian jelas mengenai pola kalimat interogatif dilihat dari struktur frasa pembentuknya. Di sisi lain, penelitian ini juga memberikan kontribusi dalam kajian sintaksis mengenai klasifikasi kalimat berdasarkan unsur pembentuknya dan dapat mempermudah pengguna bahasa dalam menerapkan setiap jenis kalimat interogatif.

Selain bentuk interogatif berdasarkan tujuannya, Caesar (2016) mengklasifikasikan bentuk interogatif menjadi dua bagian, yaitu interogatif parsial dan interogatif total. Interogatif parsial merupakan bentuk kalimat tanya yang bersifat sebagian, namun sudah menggambarkan sebuah pertanyaan. Sementara itu, interogatif total adalah kalimat interogatif yang memiliki struktur pembentuk lengkap dengan acuan kelas kata dan kategori setiap kata pembentuknya. Struktur kalimat interogatif BJ pada film "Tilik" kebanyakan menggunakan bentuk parsial, hal ini dikarenakan bahasa yang digunakan dalam film "Tilik" merupakan bentuk bahasa lisan yang sifatnya minim leksem.

Penelitian Zahra dan Mulyadi (2019) menghasilkan struktur kalimat interogatif dalam bahasa Mandailing yang terbentuk atas interogatif parsial dan interogatif total. Kalimat interogatif parsial dapat berperan sebagai spesifier (Spes) jika terletak di depan kalimat, sedangkan jika kata tanya berada di akhir kalimat maka dikatakan sebagai komplemen (C). Penelitian Mulyadi (20I0) berkaitan dengan struktur frasa preposisi dalam bahasa Indonesia yang dikaji melalui teori X-Bar menghasilkan struktur yang dapat dirumuskan sebagai berikut.

I) $F P=P^{\prime}$, Spes; $P^{\prime}=P^{\prime}$, Komp

2) $F P=p^{\prime}$, Spes; $p^{\prime}=p^{\prime}$, Ket; $p^{\prime}=P$, Komp

3) $F P=P^{\prime}$, Spes; $F P=P^{\prime}$,Spes; $P^{\prime}=P$,

$$
\text { Ket; } Y=P, \text { Komp. }
$$

Pada dasarnya analisis dengan teori X-Bar merujuk pada kategori fungsional sebuah kata tanya, seperti pada pemerlenkgap dan komplemen yang memiliki peran berbeda dalam membentuk struktur kalimat (Mulyadi, 20I0). Konsep lain dalam analisis X-Bar adalah pada penentuan frasa inti yang menduduki suatu klausa, yaitu adanya Frasa Infleksi (FI) atau Frasa Pemerlengkap (FPm). Konsep dasar tersebut telah dikembangkan oleh Budiman \& Mulyadi (2020) pada bahasa Jepang, di mana FI dan FPm merupakan dasar awal dalam menentukan struktur frasa lainnya. Struktur X-Bar di atas merupakan penerapan dalam bahasa Indonesia (BI) yang perlu diuji ulang dalam bahasa lainnya, khususnya dalam BJ. Bentuk interogatif antara BI dan BJ tidak jauh beda. Berikut merupakan contoh interogatif dalam BI dan BJ.

$$
\begin{aligned}
& \text { BI : "Ibu-ibu ini paham kan?" } \\
& \text { BI : "Ibu-ibu iki paham kan?" }
\end{aligned}
$$

Berdasarkan struktur kalimat, bentuk di atas memiliki kesamaan, sehingga analisis X-Bar dapat diproyeksikan pada Gambar I. 


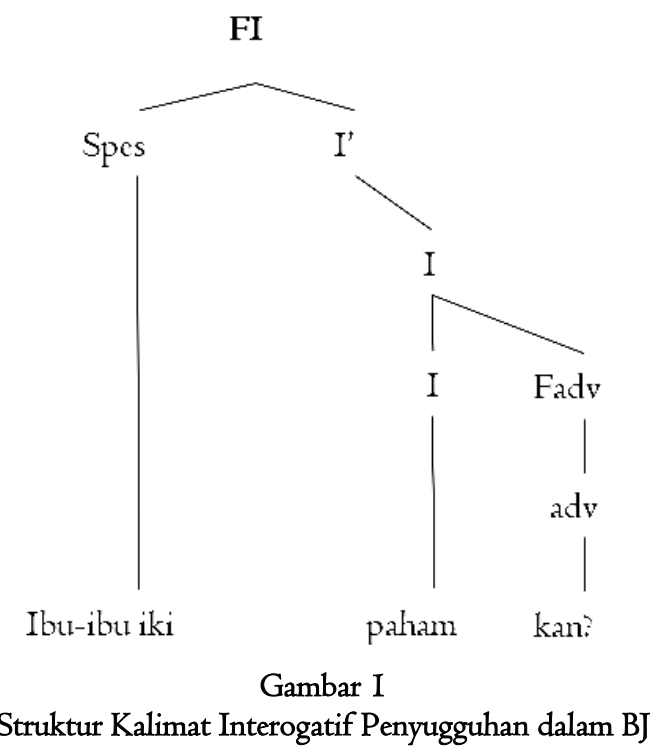

Kalimat pada Gambar I merupakan kalimat interogatif penyungguhan. Artinya, kalimat interogatif penyungguhan bertujuan untuk meyakinkan lawan tutur yang dicirikan dengan hadirnya bentuk Adv "kan". Berdasarkan uraian pada Gambar I, penelitian ini memfokuskan pada struktur interogatif BJ yang dikaji menggunakan teori X-Bar untuk melihat fungsi dan kategori kata pembentuk kalimat interogatif tersebut. Akhirnya, penelitian ini memfokuskan pada analisis struktur sintaksisnya bukan pada maksud dan tujuan dari setiap jenis kalimat interogatif. Namun begitu, penelitian ini dapat memberikan gambaran serta pemahaman jelas bahwa penggunaan teori X-Bar dapat sekaligus menemukan struktur dan juga alasan maupun tujuan dalam pemilihan bentuk penggunaan susunan kalimat interogatif tertentu. Penelitian ini diharapkan dapat memberikan wawasan lebih jauh tentang analisis X-Bar terhadap kalimat interogatif yang digunakan secara lisan.

\section{METODE}

Penelitian ini merupakan penelitian deskriptif kualitatif. Merujuk pada Santosa (2017), penelitian kualitatif merupakan penelitian yang realitas datanya bersifat multiple and holistically constructed. Artinya, data dari penelitian ini memiliki makna jamak yang dibangun secara menyeluruh dari konteksnya. Sementara itu, Sudaryanto (2018) menyatakan bahwa penelitian deskriptif merupakan penelitian yang digunakan untuk mengaji sebuah fenomena dengan tujuan memperoleh gambaran yang rinci dan akurat terhadap fenomena tersebut. Sumber data yang digunakan dalam penelitian ini berupa film pendek berjudul "Tilik" yang dirilis pada September 2018 dan disutradarai oleh Wahyu Agung Prasetyo. Dengan demikian, data yang digunakan merupakan ujaran kalimat interogatif tokoh pada film pendek tersebut.

Selanjutnya, pemerolehan data dilakukan dengan teknik simak catat. Data yang diperoleh kemudian diidentifikasi sesuai dengan jenis kalimat interogatifnya masing-masing. Seperti yang sudah disebutkan sebelumnya, Chaer (20I5) mengklasifikasikan kalimat interogatif menjadi lima bagian; (I) kalimat interogatif yang meminta jawaban 'ya' atau 'tidak', (2) kalimat interogatif yang meminta jawaban dari unsur kata tanya (apa, siapa, dimana, berapa, dan kapan), (3) kalimat interogatif yang meminta jawaban berupa 'alasan', (4) kalimat interogatif yang meminta jawaban berupa 'pendapat', dan (5) kalimat interogatif yang meminta jawaban 'menyungguhkan'. Data-data yang telah diidentifikasikan dan diklasifikasikan sesuai jenisnya kemudian dianalisis dengan menggunakan metode agih serta teori X-Bar milik Noam Chomsky. Dalam metode agih, alat penentu yang digunakan adalah bahasa itu sendiri, seperti kata (adverbia, kata ingkar, preposisi, dll.), fungsi sintaksis (subjek, predikat, objek, dll), klausa, silabe kata, titik nada, dan lain sebagainya. Metode agih memiliki teknik dasar yang disebut dengan teknik bagi unsur langsung (Sudaryanto, 2018). 
Fitriyani \& Mulyadi, (2017) menyebutkan bahwa teori X-Bar pertama kali diusulkan oleh Noah Chomsky pada tahun 1970. Lebih lanjut, Caarnie (202I) menyatakan bahwa analisis X-Bar merupakan teori yang digunakan untuk menganalisis struktur sebuah frasa. Dalam sebuah frasa, terdapat satu inti leksikal yang mendominasi frasa tersebut. Inti leksikal ini merupakan head dari frasa tersebut. Selaras dengan pernyataan Haegeman (2006) yang menyatakan bahwa frasa termasuk golongan endosentris yang mana berarti bahwa sebuah frasa merupakan proyeksi atau inti (head) dari keseluruhan frasa tersebut. Dengan begitu, apabila inti dari sebuah frasa merupakan nomina, maka frasa ini termasuk ke dalam frasa nomina dan apabila inti dari sebuah frasa merupakan verba, maka frasa tersebut merupakan frasa verba dan demikian seterusnya (Gapur, 2018; Prihatini, 2019). Lebih lanjut, Haegeman (ibid) memaparkan bahwa struktur frasa menurut teroi X-Bar sebagai berikut.

I) $X^{\prime \prime} \rightarrow \operatorname{Spec} ; X^{\prime}$

2) $X^{\prime} \rightarrow X^{\prime} ; Y P$

3) $X^{\prime} \rightarrow X ; Y P$

(dimodifikasi dari Pujiono, 20I4)

Dengan demikian, apabila gambaran di atas dipaparkan lebih jauh, maka teori X-Bar dapat digambarkan pada Gambar 2 sebagai berikut.

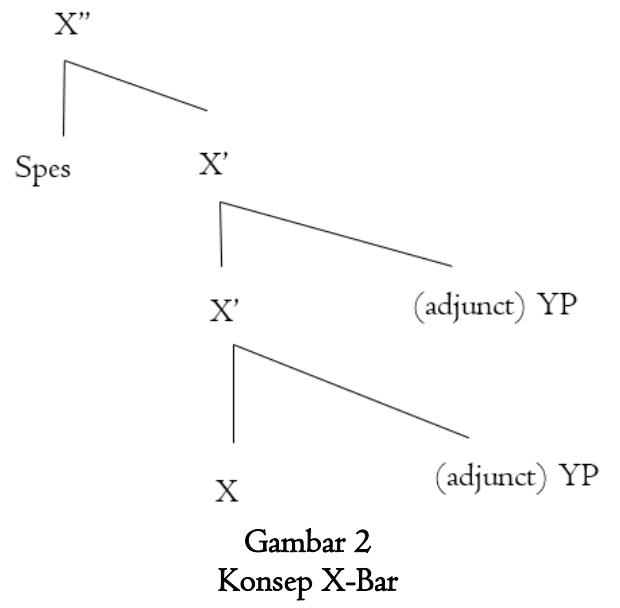

Berdasarkan diagram pohon pada Gambar 2, posisi cabang yang paling kiri disebut dengan 'spes' yang merupakan inti dari sebuah frasa. Sementara itu, dua cabang di sebelah kanan yang disebut dengan 'YP' merupakan objek ataupun komplemen dari sebuah frasa tersebut.

Lebih lanjut, saat ini analisis dengan menggunakan X-Bar teori tidak hanya terbatas pada struktur frasa saja (Kebbe, 2000). Sawirman (2007) menyatakan bahwa pada awalnya teori X-Bar memang hanya diterapkan pada analisis struktur frasa saja. Namun, saat ini penerapan teori X-Bar dalam analisis sintaksis melebar ke dalam tataran klausa maupun tataran kalimat. Penganalisisan struktur sintaksis terhadap sebuah klausa maupun kalimat dilakukan dengan cara yang sama yaitu menggunakan kaidah penganalisisan struktur sintaksis seperti pada tataran frasa (Al-Qumairi et al., 2020; Budiman \& Mulyadi, 2020). Akhirnya, analisis dengan teori X-Bar merupakan analisis yang akurat untuk mengidentifikasikan serta menggambarkan bagaimana sebuah frasa maupun klausa memberikan fungsi pada setiap kategori kata (Zahra \& Mulyadi, 2019).

Berkaitan dengan paparan di atas, analisis data dalam penelitian ini diawali dengan menyimak penggunaan kalimat interogatif yang terdapat dalam film "Tilik" dan mengklasifikasikannya ke dalam jenis-jenis kalimat interogatif yang telah disebutkan. Selanjutnya, data yang telah diklasifikasikan tersebut dianalisis dengan metode agih dengan teknik dasar dan teknik lanjutan berupa teknik bagi unsur langsung. Hasil segmentasi atau konstituen-konstituen tersebut kemudian dibuat ke dalam 
diagram pohon X-Bar dengan menentukan 'spes' atau inti serta komplemen dan keterangan dari frasa tersebut. Teori X-Bar digunakan untuk melihat struktur kalimat interogatif yang terdapat dalam bahasa Jawa pada film "Tilik".

\section{HASIL DAN PEMBAHASAN}

\section{Struktur Kalimat Interogatif}

Kalimat interogatif pada film "Tilik" mempunyai bentuk yang cukup bervariatif. Dilihat dari segi struktur, masing-masing jenis kalimat interogatif memiliki ciri khas tersendiri. Hal ini dapat dibuktikan melalui analisis struktur kalimat interogatif melalui teori X-Bar yang akan dipaparkan pada penelitian ini. Temuan data terkait bentuk kalimat interogatif dikelompokkan dalam jenis interogatif berdasarkan tujuannya yang meliputi interogatif pengakuan ya-tidak, interogatif meminta jawaban mengenai suatu unsur, interogatif alasan, interogatif pendapat, dan interogatif penyungguhan. Berikut merupakan bentuk kalimat interogatif yang ditemukan oleh peneliti dalam film "Tilik" karya Wahyu Agung Prasetyo sebagaimana pada Tabel I.

Tabel I

Data Kalimat Interogatif pada Film "Tilik"

\begin{tabular}{llc}
\hline \multicolumn{1}{c}{ Jenis Interogatif } & Kalimat & Sifat \\
\hline Interogatif pengakuan ya-tidak & "Wis tak lebokne amplop ya iki?" & Total \\
Interogatif meminta jawaban suatu unsur & "Jam pira lho saiki?" & Parsial \\
Interogatif alasan & "Ngapa ta ora nganggo bis wae?" & Parsial \\
Interogatif pendapat & "Sing dadi lurah Dian wae piye?" & Parsial \\
& "Sidane mangkat tekan kene ra iso tilik, piye bu?" & Parsial \\
Interogatif penyungguhan & "Dadi aku ta sing kleru bu?" & Total \\
& "Ibu-ibu ini paham kan?" & Total \\
\hline
\end{tabular}

Penjelasan mengenai struktur kalimat interogatif dalam teori X-Bar berkaitan dengan fungsi gramatikal yang meliputi Pemerlengkap (Pm), Infleksi (I), Spesifier (Spes), dan Komplemen (Komp). Lebih lanjut, fungsi tersebut dalam penerapannya di dalam teori X-Bar membentuk sebuah kategori frasa yang meliputi Frasa Pemerlengkap (FPm), Frasa Infleksional (FI), Frasa Nominal (FN), Frasa Verbal (FV), Frasa Adverbial (Fadv), dan Frasa Pronominal (FP). Kategori tersebut merupakan kategori utama dalam BI, namun ada beberapa kategori yang digunakan dalam BJ, seperti Partikel (Part) dan Interjeksi (Int). FPm merupakan konstruksi yang paling tinggi dalam sebuah kalimat interogatif, sehingga struktur interogatif bahasa Jawa dalam film "Tilik" dapat diproyeksikan berdasarkan kategori pembentuknya. Kategori pembentuk interogatif memiliki dua pola struktur yang meliputi, $(F P m+$ Spes $+I+$ Komp $)$ dan $(I+S p e s+$ Komp $)$.

\section{Strtuktur Interogatif FPm + Spes $+I+$ Komp}

Seperti penjelasan sebelumnya, bentuk kalimat interogatif dengan kategori penyusun FPm memiliki konstruksi yang paling tinggi. Kalimat interogatif dengan struktur FPm+Spes+I+Komp terdapat pada kalimat (I) tepatnya pada jenis interogatif meminta alasan. Ciri utama pada bentuk kalimat interogatif meminta alasan umumnya menggunakan kata ganti tanya ngapa mengapa'. Bentuk interogatif ini berdasarkan sifatnya termasuk ke dalam interogatif parsial, artinya kalimat tanya yang hanya meminta informasi sebagian dari pertanyaan itu. Gambar 3 berikut merupakan bentuk analisis XBar pada kalimat (I).

(I) "Ngapa ta ora nganggo bis wae?"(Mengapa tidak menggunakan bis saja?) 


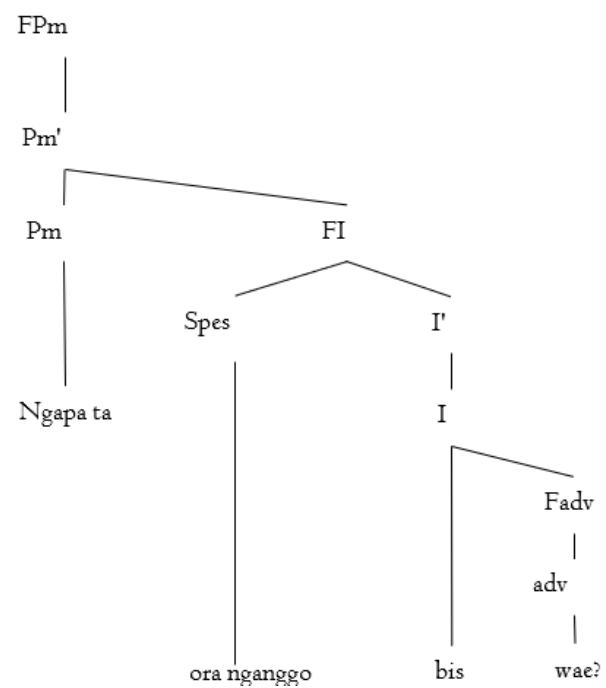

Gambar 3

Struktur Interogatif X-Bar pada Data I

Diagram X-Bar di atas merupakan representasi dari struktur kalimat tanya "ngapa ta ora nganggo bis wae?" yang dibentuk oleh hadirnya pemerlengkap sebagai tataran tertinggi dari kalimat tanya tersebut. Proyeksi dari pemerlengkap pada kalimat interogatif ini bersifat wajib disebabkan oleh penggunaan kata tanya (WH-Question) ngapa yang berarti 'kenapa'. Kalimat interogatif "ngapa ta ora nganggo bis wae?" dibangun oleh inti leksikal bis yang kemudian berkombinasi dengan komplemen wae yang selanjutnya membentuk infleksi-bar. Kemudian, infleksi-bar pada tataran ini berkombinasi dengan spesifier ora nganggo yang membentuk frasa infleksi bar. Selanjutnya, dihubungkan oleh pemerlengkap ngapa ta untuk mencapai proyeksi frasa pemerlengkap pada tataran tertinggi.

(2) "Sidane mangkat tekan kene ra iso tilik, piye bu?" (Jadinya berangkat nyampek sini nggak bisa jenguk, bagaimana bu?

Kemudian, pada data 2 "Sidane mangkat tekan kene ra iso tilik, piye bu?" juga ditemukan penggunaan kalimat interogatif parsial yang diawali Fpm yang diawali pelengkap 'sidane' kemudian berkomplemen dengan spesifier dan inti 'mangkat tekan kene' yang diakhiri dengan nomina 'bu'. sebagaimana dalam Gambar 4 berikut.

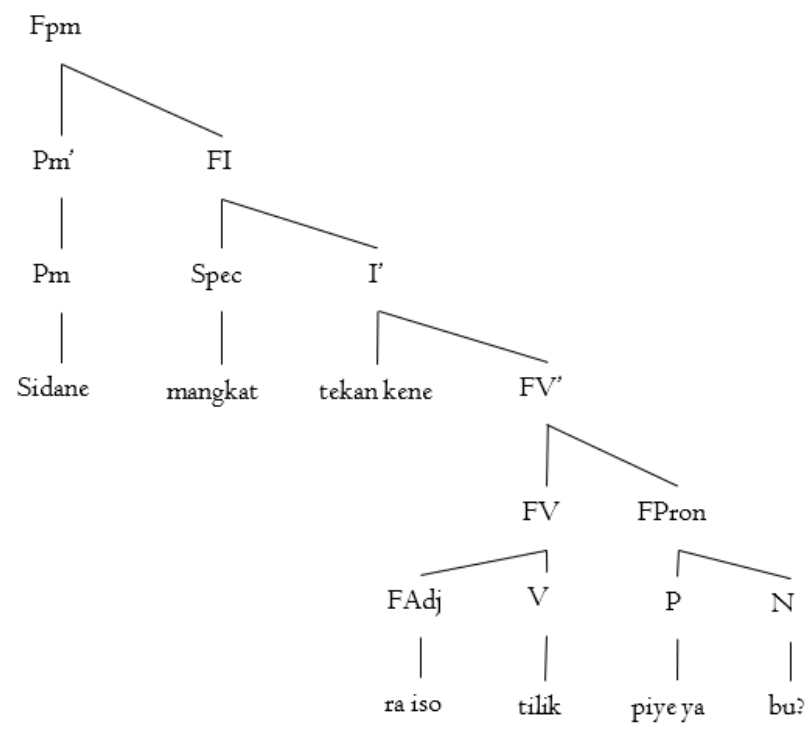

Gambar 4

Struktur Interogatif X-Bar pada Data 2 
Kalimat (2) merupakan interogatif meminta pendapat yang memiliki struktur kalimat sama seperti pada data kalimat (I). Penggunaan Fpm di awal kalimat menandakan jenis kalimat interogatif parsial di mana penutur tidak menggunakan jenis interogatif total. Dengan begitu, pendominasian dalam interogatif alasan yaitu frasa pemerlengkap yang muncul terlebih dahulu sebelum FI. Sebagaimana yang sudah disebutkan sebelumnya, pendominasian jenis interogatif parsial disebabkan karena penggunaan bahasa lisan. Dengan begitu, merujuk pada Tabel I, dapat disimpulkan bahwa film "Tilik" menggunakan struktur parsial pada jenis interogatif alasan maupun interogatif pendapat yang disebabkan karena penggunaan bahasa lisan. Struktur kalimat tanya dalam jenis interogatif alasan di atas dapat dijabarkan pada Gambar 5 sebagai berikut.

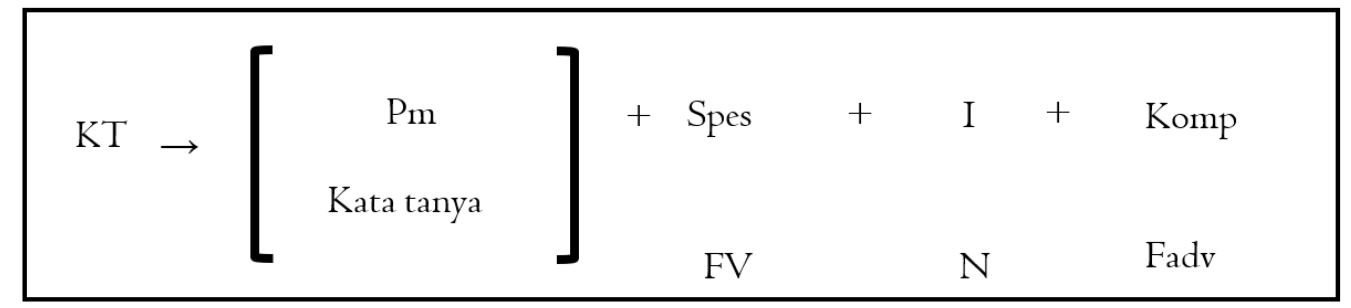

Gambar 5

Struktur Interogatif Jenis Alasan

Seperti yang sudah disebutkan sebelumnya, jenis interogatif alasan pada film "Tilik" berkategori sebagai pemerlengkap dengan menggunakan kata ngapa 'mengapa' sebagai kata tanya ( $\mathrm{WH}$ Question). Kata ngapa inilah yang menentukan bahwa bentuk kalimat tanya "ngapa ta ora nganggo bis wae?" merupakan bentuk kalimat interogatif jenis alasan. Chaer (20I5) menyatakan bahwa jenis kalimat tanya interogatif dibentuk oleh penggunaan kata 'mengapa' dan 'kenapa'. Lebih lanjut, Penelitian Budiman \& Mulyadi (2020) menghasilkan sebuah konsep bahwa pemerlengkap (Pm) merupakan unsur klausa yang menentukan tipe klausa yang mengikutinya. Bentuk pemerlengkap berdasarkan hasil penelitian Budiman dan Mulyadi tersebut berlaku pada bahasa Jepang, di mana hanya pada kata tanya kenapa, siapa, dari mana, ke mana, di mana, dan kapan. Berbeda dengan konsep kata tanya dalam kalimat interogatif di atas, Zahra \& Mulyadi (2019) memfokuskan analisisnya pada peletakan kata tanya dalam kalimat interogatif. Peletakan kata tanya menurutnya sangat berpengaruh pada fungsi komplemen antar frasa. Apabila kata tanya diletakkan di akhir kalimat, maka memiliki fungsi komplemen. Fungsi tersebut telah dikembangkan dalam bahasa Mandailing bahwa kata tanya apa, siapa, kapan, mengapa, di mana, dan bagaimana dalam kalimat interogatif memiliki fungsi yang sama, yaitu merujuk pada fungsi leksikal kata benda.

Berdasarkan pandangan peneliti sebelumnya dan teori X-Bar yang diturunkan dari Noam Chomsky, kata tanya dalam kalimat interogatif memiliki struktur yang diisi oleh pemerlengkap dengan fungsi dan peran yang berbeda, bergantung pada pola kalimat bahasa tertentu (Morley, 2004; Muller, 2018). Fokus bahasa yang digunakan dalam penelitian menggunakan bahasa Jawa di mana pemerlengkap dalam bahasa Jawa dapat diisi oleh kata tanya ngapa 'mengapa'. Peletakan kata tanya dalam interogatif bahasa Jawa juga dapat menimbulkan perbedaan fungsi, namun yang menjadi fokus dalam hal ini bahwa peletakan pemerlengkap kata tanya di awal kalimat dapat membentuk proyeksi frasa pada tataran tertinggi. Melalui ulasan tersebut, dapat disimpulkan bahwa kata ngapa sebagai pemerlengkap menjadikan kalimat tanya "ngapa ta ora nganggo bis wae?" sebagai jenis introgatif alasan.

\section{Struktur Interogatif I+Spes + Komp}

Kalimat interogatif dengan struktur I+Spes+Komp terjadi pada interogatif yang memiliki kata ganti tanya di tengah atau di belakang kalimat. Letak kata ganti tanya dalam struktur interogatif memengaruhi struktur FPm atau tanpa FPm (langsung FI). Berikut merupakan uraian struktur interogatif pada pola FI. 
(3) “Wis tak lebokne amplop ya iki?” (Sudah saya masukkan amplop ya ini?)

Kalimat (3) merupakan interogatif yang bermodus penegasan. Artinya bahwa penegasan ini ditujukan untuk menanyakan kembali terkait kebenaran pada unsur tertentu. Kalimat (3) pada dasarnya merupakan bentuk representasi penegasan yang ditandai dengan kata ya dengan pelafalan [yo]. Kata wis dan ya berkolaborasi dalam membentuk penegasan penuh yang bertujuan agar mitra tutur memberikan jawaban berupa kepastian iya [iyo] atau ora [ora] 'tidak'. Munculnya kata tak dalam BJ termasuk dalam afiks gabungan yang dapat mengubah makna. Dikonversi dalam Bahasa Indonesia kata tak ini termasuk dalam kategori pronomina orang pertama tunggal. Tak lebokne dapat diartikan dengan 'saya masukkan'. Adapun bentuk struktur X-Bar pada kalimat (3) digambarkan pada Gambar 6 sebagai berikut.

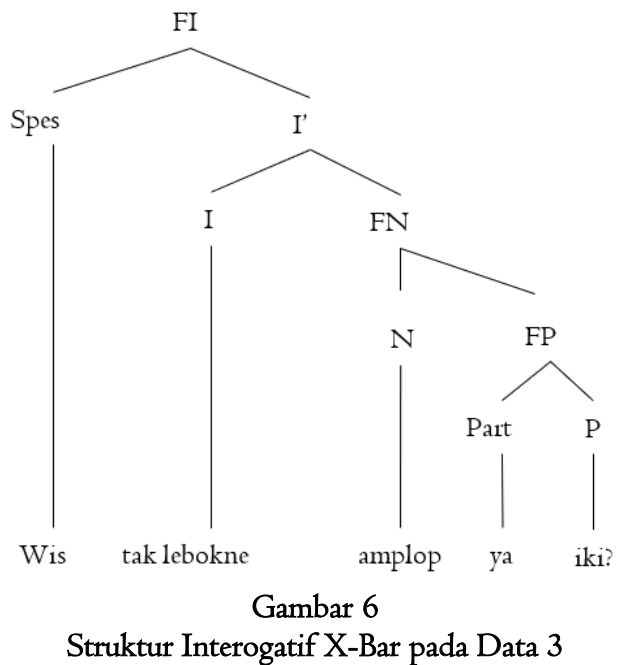

Berdasarkan diagram X-Bar pada kalimat (3), kalimat interogatif "wis tak lebokne amplop ya iki?" terbentuk dari infleksi yang didampingi oleh dua kategori komplemen (FN dan FP) dan spesifier. Struktur ini menggambarkan jenis interogatif penegasan. Kalimat klausa "wis tak lebokne amplop ya iki?" dibentuk oleh proyeksi tak lebokne 'saya masukkan' sebagai inti leksikal. Kata ya dan iki berkombinasi membentuk FP yang kemudian berkombinasi dengan kata amplop untuk membentuk FN. Selanjutnya, infleksi tak lebokne berkombinasi dengan FN amplop untuk membentuk infleksi-bar. Kemudian, spesifier wis berkombinasi dengan infleksi-bar untuk membentuk proyeksi maksimal frasa infleksi (FI).

Kalimat pada Data 3 merupakan sebuah penegasan dalam menanyakan sebuah peristiwa pembuktian. Bentuk interogatif tersebut merupakan jenis kalimat interogatif yang meminta pengakuan jawaban 'ya' atau 'tidak'. Chaer (2015) menguraikan bahwa kalimat interogatif penegasan 'ya' atau 'tidak' dapat dicirikan dengan adanya pemberian intonasi tanya pada sebuah klausa atau kalimat, dalam bahasa tulis intonasi tanya ini dilambangkan dengan tanda tanya (?). Konsep interogatif yang dikemukakan oleh Chaer (2015) ini nampaknya cukup kontras jika dibandingkan dengan pola struktur kalimat dalam teori X-Bar. Pada teori X-Bar, satuan leksikal merupakan wujud utama dalam sebuah kalimat dan menganggap bahwa tanda baca hanya berperan sebagai fungsi satuan kalimat secara tekstual bukan secara struktur leksikal (Caesar, 2016; Gapur, 2018).

Lebih lanjut, teori X-Bar memberikan pandangan bahwa struktur dalam interogatif dapat diwujudkan dengan menitikberatkan pada satuan leksikalnya, bukan pada tanda tanya (?). Kalimat (3) pada dasarnya terdiri dari dua bentuk komplemen yaitu FN dan FP. Frasa tak lebokne 'saya masukkan' berperan sebagai inti leksikal yang kemudian dapat diproyeksikan penuh dengan penambahan frasa ya iki 'iya ini'. Kedua bentuk tersebut jika digabungkan merepresentasikan sebuah penegasan kembali yang ingin meminta jawaban ya atau tidak. Berdasarkan ulasan tersebut, kalimat interogatif "wis tak lebokne amplop ya iki?" dapat dikategorikan ke dalam interogatif untuk meminta jawaban kepastian ya atau 
tidak. Ada tidaknya tanda tanya (?) bukan menjadi inti leksikal dalam interogatif berdasarkan teori XBar yang telah dikemukakan sebelumnya.

(4) "Jam pira lho saiki?" (Jam berapa sekarang?)

Kalimat (4) merupakan kalimat yang menanyakan terkait unsur tertentu. Lebih jelas, unsur tersebut adalah menanyakan terkait waktu, dengan penanda kata jam lalu diikuti kata ganti tanya pira [piro] 'berapa'. Penambahan kata tho pada kalimat (4) merupakan interjeksi yang bermakna seruan atau ungkapan verbal yang bersifat emotif. Selanjutnya, struktur X-Bar pada kalimat (4) digambarkan pada Gambar 7 sebagai berikut.

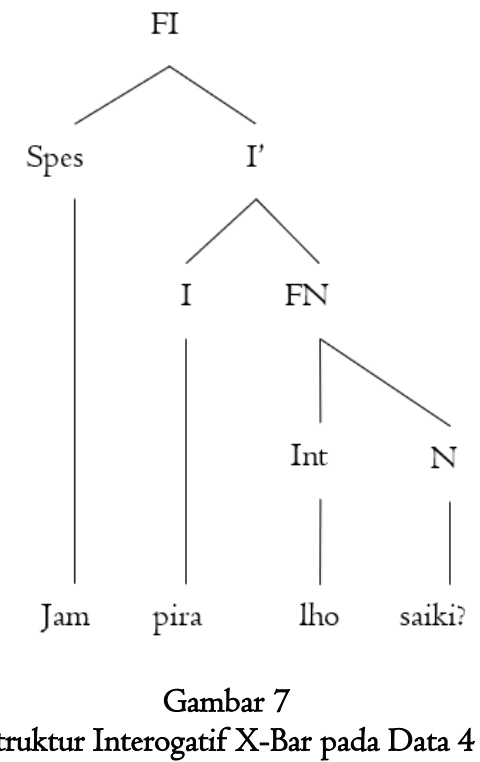

Diagram X-Bar pada kalimat (4) dibentuk dari infleksi yang didampingi oleh satu kategori komplemen (FN) dan spesier. Kalimat interogatif "Jam pira lho saiki?" termasuk ke dalam jenis interogatif menanyakan sebuah unsur tertentu. Unsur yang ditanyakan adalah waktu dengan penanda kata ganti tanya pira 'berapa'. Selain itu, kata pira dalam struktur tersebut merupakan inti leksikal yang memproyeksikan sebuah interogatif menanyakan tentang waktu (jam). Kategori komplemen FN dibentuk atas 2 kelas kata yaitu interjeksi dan nomina. Kata Iho dalam BJ termasuk dalam jenis interjeksi atau kata yang menggambarkan sebuah seruan perasaan (Mulyono, 20II). Selanjutnya, kata saiki 'berapa' merupakan bentuk nomina yang berkontribusi sebagai unsur inti dalam FN tho saiki. Infleksi kata pira berkombinasi dengan kategori FN, sehingga membentuk infleksi-bar (I'). Spesifier pada kata jam berkombinasi dengan infleksi-bar membentuk proyeksi yang paling tinggi, yaitu frasa infleksi (FI).

Kata tanya dalam setiap bahasa memiliki berbagai bentuk perbedaan. Namun, secara pasti kata tanya digunakan dalam sebuah interogatif secara terstruktur berdasarkan pasangan dan letak setiap leksikal kata tanya. Penelitian sebelumnya terkait dengan kata tanya hanya memfokuskan pada jenis kenapa, siapa, dari mana, ke mana, di mana, apa, dan bagaimana (Mulyadi, 20I0; Zahra \& Mulyadi, 2019). Kedua penelitian tersebut hanya menguraikan distribusi tujuh kata tanya yang dipaparkan berdasarkan teori X-Bar. Bentuk kata tanya piro 'berapa' merupakan bentuk kata tanya yang umum ada dalam bahasa Jawa dan bahasa Indonesia. Penggunaan kata piro pada kalimat (4) berperan sebagai inti leksikal yang membentuk infleksi-bar pada pasangan spesier. Berdasarkan ulasan tersebut, kata tanya piro 'berapa' memiliki peran yang sama dengan kata tanya lainnya, hanya saja dibedakan berdasarkan letak dan pasangan frasa yang melekat pada kata tersebut.

(5) "Sing dadi lurah Dian wae piye?”(Yang jadi lurah Dian saja bagaimana?) 
Kalimat (5) merupakan bentuk interogatif meminta pendapat lawan tutur terkait permasalahan pengganti lurah yang ditujukan kepada Dian. Kalimat (5) memiliki sifat parsial dengan kata ganti tanya yang berada di belakang kalimat. Kata piye 'bagaimana' menanyakan terkait sebuah pendapat yang bertujuan untuk mengharapkan jawaban verbal secara lengkap. Berkaitan dengan hal tersebut, perlu diuraikan secara struktural dengan menggunakan analisis X-Bar seperti pada Gambar 8 berikut.

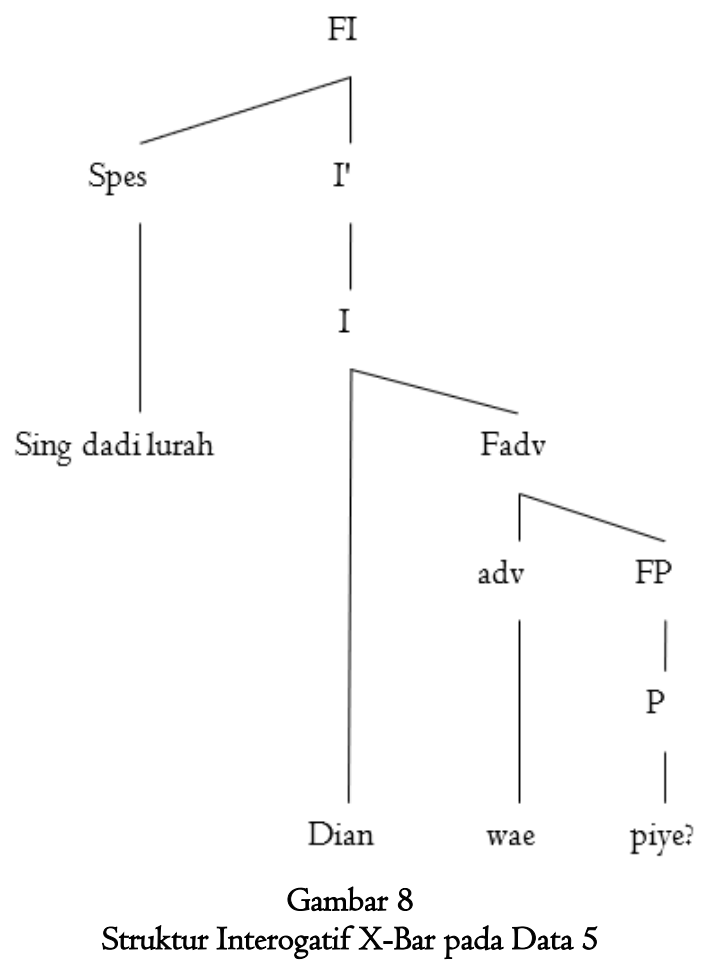

Berdasarkan diagram X-Bar di atas, klausa "Sing dadi lurah Dian wae piye?" juga terbentuk dari infleksi yang didampingi oleh dua kategori komplemen (FAdv dan FP) dan spesifier. Struktur ini menggambarkan jenis interogatif pengakuan ya-tidak. Kalimat klausa "Sing dadi lurah Dian wae piye?" dibentuk oleh proyeksi Dian sebagai inti leksikal. Kata wae (adverbia) berkombinasi dengan pie (pronominal) yang kemudian membentuk FAdv. Infleksi Dian berkombinasi dengan FAdv yang membentuk Infleksi-Bar, yang mana Infleksi-Bar ini berkombinasi dengan spesifer sing dadi lurah, sehingga pembentukan proyeksi maksimal frasa infleksi (FI) tercapai.

Peletakan kata tanya menurutnya sangat berpengaruh pada fungsi komplemen antar frasa. Apabila kata tanya diletakkan di akhir kalimat, maka memiliki fungsi komplemen. Selaras dengan temuan pada kalimat (5) di atas, bahwa kata piye 'bagaimana' diletakkan di akhir kalimat interogatif, sehingga membentuk proyeksi frasa pada tataran tertinggi. Namun, bentuk tersebut memiliki fungsi yang berbeda jika kata piye 'bagaimana' diletakkan di awal kalimat, maka frasa yang dibentuk bukan lagi menjadi Fadv dan unsur spesifier akan hilang. Spesifier pada bentuk sing dadi lurah 'yang jadi lurah' menjadi penentu utama dalam kalimat interogatif tersebut. Lebih lanjut, fungsi spesifier tersebut adalah untuk menerangkan frasa berikutnya yang secara eksplisit menanyakan mengenai pendapat yang dicirikan dengan kata tanya piye 'bagaimana.

(6) "Dadi aku ta sing kleru bu?" (Jadi aku ya yang salah bu?)

Kalimat (6) merupakan jenis interogatif penyungguhan. Penanda penyungguhan dalam kalimat (6) adalah pada kata ta [to]. Istilah ta dalam BJ termasuk dalam kata seru yaitu kata yang dipakai untuk menyatakan atau melahirkan rasa (Mulyono, 20II). Penggunaan kata seru ta dalam kalimat (6) berperan sebagai penegas yang merujuk pada penyungguhan atas kesadaran telah melakukan kekeliruan. 
Selanjutnya kata ta diikuti dengan frasa sing kleru 'yang keliru' menjadikan kalimat (6) sebagai bentuk interogatif penyungguhan. Berikut merupakan bagan struktur interogatif dengan menggunakan X-Bar pada kalimat (6).

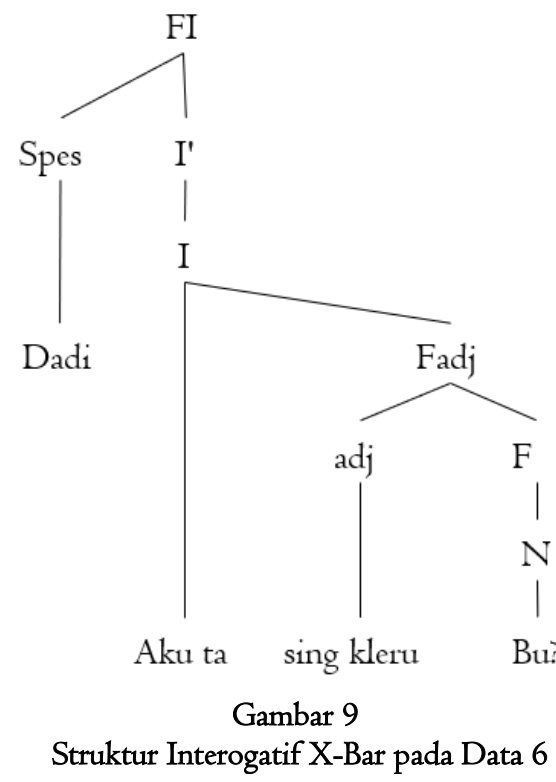

Diagram X-Bar di atas merupakan penjabaran dari interogatif penyungguhan. Di dalam klausa tanya "dadi aku ta sing kleru bu?" terbentuk dari dua kategori komplemen (Fadj dan FN) dan spesifier. Proyeksi inti leksikal dalam klausa ini yaitu aku ta. Jika dianalisis lebih jauh, nominal bu yang berkombinasi dengan adjektiva sing kleru membentuk Fadj. Kemudian, Fadj ini berkombinasi dengan infleksi aku ta yang pada akhirnya membentuk proyeksi dari Infleksi-Bar. Infleksi-Bar ini kemudian berkombinasi dengan spesifier dadi, sehingga terbentuk proyeksi maksimal dari frasa infleksi.

Kalimat (6) pada secara struktur X-Bar, susah untuk melihat jenis interogatifnya karena tidak ada kata tanya yang secara langsung terdapat dalam susunan kalimat tersebut. Kalimat tersebut termasuk dalam jenis interogatif penyungguhan yang ditandai dengan frasa aku to 'aku ini' dan sing kleru 'yang salah. Chaer (20I5) telah menguraikan bahwa interogatif penyungguhan dapat dicirikan dengan intonasi tanya. Konsep intonasi tanya tersebut berlaku dalam bahasa Indonesia. Mulyono (2011) menyatakan bahwa konsep tersebut berbeda dengan bahasa Jawa yang menganggap bahwa dalam interogatif dimungkinkan adanya kata seru dengan tujuan untuk menyungguhkan. Teori yang dikembangkan oleh Mulyono tersebut menjadi penguat dalam temuan data pada kalimat (6) bahwa, hadirnya kata to berperan sebagai kata seru yang sekaligus menyungguhkan terkait pernyataan yang diminta.

(7) "Ibu-ibu ini paham kan?”(Ibu-ibu ini paham kan?)

Kalimat (7) merupakan jenis interogatif penyungguhan. Sebagaimana yang ditampilkan pada table I, diketahui bahwa interogatif penyungguhan dalam film ini menggunakan struktur total yang diawali oleh FI. Interogatif ini berisikan spesifier berupa "ibu-ibu inl" sedangkan inti dari kalimat interogatif ini yaitu kata "paham" yang berdiri sebagai pertanyaan penyungguhan kepada mitra tutur. Kalimat interogatif penyungguhan diawali oleh FI ditujukan untuk menekankan pada inti dari interogatif itu sendiri. Berikut merupakan bentuk X-Bar dari kalimat (7). 


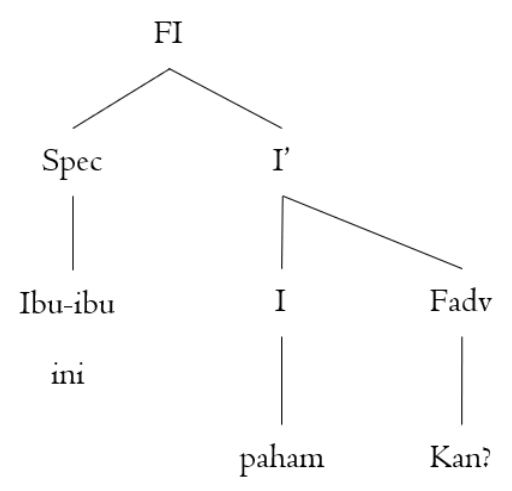

\section{Gambar I0}

Struktur Interogatif X-Bar pada Data 7

Diagram X-Bar di atas merupakan penjabaran dari interogatif penyungguhan dengan pemarkah kan. Pada kalimat "Ibu-ibu ini paham kan?" merupakan wujud dari bahasa Jawa yang sekaligus memiliki bentuk yang sama dalam bahasa Indonesia. Artinya, ada unsur perubahan leksikon yang didasarkan perbendaharaan kata yang dimiliki penutur. Inti leksikal dalam kalimat (7) terdapat pada kata seru kan yang sekaligus sebagai penanda terkait penyungguhan. Adanya pemarkah kan sebagai kata seru dalam BJ ini selaras dengan pernyataan Mulyono (20II) yang menguraikan bahwa dalam kalimat interogatif bahasa Jawa dimungkinkan adanya kata seru dengan tujuan untuk menyungguhkan. Penggunaan kan dalam kalimat (7) merupakan representasi dari infleksi bar yang dibentuk atas dasar I dan Fadv.

\section{Konstruksi Kalimat Interogatif Berdasarkan Analisis X-Bar}

Bentuk struktur interogatif berdasarkan analisis X-Bar pada ketujuh data di atas, menghasilkan sebuah proyeksi dua struktur X-Bar yang meliputi, $(F P m+I+S p e s+K o m p)$ dan $(I+S p e s+K o m p)$. Kedua proyeksi tersebut berawal dari temuan Mayasari \& Mulyadi (2020) yang memfokuskan pada pola komplemen (C) dan spesfier (Spes) dalam bahasa Jawa. Konsep dasar mengenai komplemen dan spesifier kemudian peneliti konstruksikan berdasarkan data yang ditemukan, sehingga muncul kedua pola tersebut yang mengarah pada inti leksikal FPm dan I, di mana I terbentuk atas dasar C dan Spes. Struktur yang terdapat kategori FPm merupakan proyeksi yang paling tinggi, artinya letak kata ganti tanya berada pada awal kalimat yang berperan sebagai spesifier komplemen (Harahap \& Mulyadi, 2018; Mayasari \& Mulyadi, 2020). Bentuk pada struktur pertama ini terdapat pada kalimat interogatif meminta alasan dengan unsur inti terletak pada kata ganti tanya ngapa 'mengapa'. Secara holistik, kategori FPm ini berada pada interogatif yang memiliki sifat parsial. Sebaliknya, pada interogatif yang memiliki sifat total memiliki bentuk struktur X-Bar tanpa FPm, atau membentuk Frasa Infleksi (FI) secara langsung, sehingga kedua struktur interogatif di atas dapat dikonstruksikan sebagai berikut.

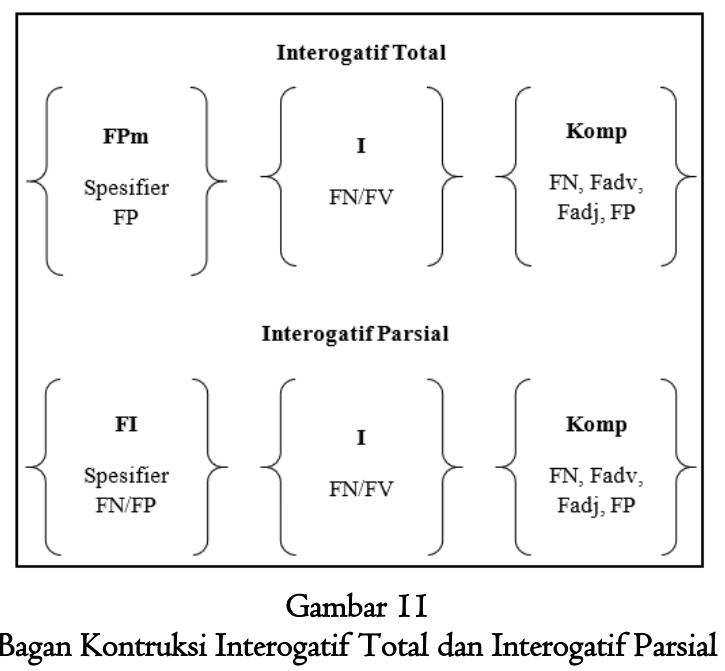

KEMBARA: Jurnal Keilmuan Bahasa, Sastra, dan Pengajarannya, Volume 7, Nomor 1, April 2021, halaman 53-70 
Bagan konstruksi interogatif di atas, dibentuk atas dasar variasi interogatif secara lisan yang merujuk pada bentuk interogatif total dan interogatif parsial. Berbeda dengan penelitian Zahra dan Mulyadi (2019) yang mendeskripsikan bentuk kalimat interogatif parsial dan total berdasarkan unsur kalimat tanpa menekankan pada frasa pembentuknya. Penelitian ini menghasilkan sebuah pola yang mengacu pada pemarkah total dan parsial lebih mendalam. Berdasarkan konstruksi interogatif total dan interogatif parsial di atas, kalimat interogatif dapat diklasifikasikan ke dalam bentuk total maupun parsial berdasarkan proyeksi frasa pembentuknya. Interogatif total memiliki pola FPm yang terdiri dari spesifier dan FP jika kata ganti tanya berada di awal kalimat. Selanjutnya diikuti oleh frasa infleksional seperti FN atau FV yang berkontribusi dengan Komp: FN, Fadv, Fadj, dan FP. Bentuk yang kedua yaitu pada interogatif parsial tidak memiliki unsur FPm dikarenakan letak kata ganti tanya tidak berada di depan kalimat. Letak kata ganti tanya pada interogatif parsial FI berada di tengah atau di akhir kalimat interogatif. Konstruksi seperti ini merupakan representasi dari distribusi kalimat interogatif dalam penerapannya secara lisan, baik interogatif total maupun interogatif parsial.

Perbedaan konstruksi total dan parsial di atas menggambarkan adanya bentuk yang berbeda dalam interogatif BJ yang diakibatkan pada letak kata ganti tanya. Secara maksud dan tujuannya, model interogatif ini pada intinya sama-sama menanyakan sesuatu hal. Namun, secara struktur sintaksisnya berbeda. Perbedaan ini dapat mempengaruhi struktur interogatif BJ yang mengarah pada letak distribusi struktur X-Bar FPm dan FI. Zahra \& Mulyadi (2019) menegaskan bahwa kalimat tanya parsial dikatakan sebagai spesifier jika kata tanya diletakkan di awal kalimat. Sebaliknya, dapat dikatakan sebagai komplemen jika kata tanya berada di akhir kalimat. Berdasarkan bagan konstruksi interogatif pada Gambar II memberikan gambaran bahwa, tidak semua jenis interogatif total dan parsial samasama memiliki struktur FPm ataupun FI. Distribusi setiap jenis interogatif memiliki bentuk yang dapat digambarkan pada Tabel 2 berikut.

Tabel 2

Distribusi Interogatif pada Pola FPm \& FI

\begin{tabular}{llcccc}
\hline \multicolumn{1}{c}{ Jenis Interogatif } & Total & Parsial & Pm & I \\
\hline (I) Interogatif pengakuan ya-tidak & + & - & - & + \\
(2) Interogatif meminta jawaban mengenai suatu unsur & - & + & $-/+$ & + \\
(3) Interogatif alasan & - & + & + & $+/-$ \\
(4) Interogatif pendapat & - & + & $-/+$ & + \\
(5) Interogatif penyungguhan & + & - & - & + \\
\hline
\end{tabular}

Interogatif yang memiliki pola FPm secara mandiri terletak pada jenis interogatif meminta alasan yang bersifat parsial. Secara mutlak, interogatif yang bersifat total, tepatnya pada interogatif pengakuan ya-tidak dan interogatif penyungguhan memiliki pola FI. Distribusi ini memberikan gambaran bahwa interogatif total memiliki pola FI secara mandiri. Kemutlakan bentuk FI ini dikarenakan pada interogatif total hanya menanyakan terkait penegasan atau penyugguhan yang dicirikan dengan hadirnya kata ya, ta, dan kan. Keduanya merupakan partikel yang melekat pada sebuah frasa dalam tataran kalimat interogatif. Bentuk partikel ini dalam BJ terletak di akhir kalimat dan bukan termasuk dalam kategori kata ganti tanya, itu sebabnya interogatif total secara mutlak terdistribusi pada pola FI. Distribusi berdasarkan Tabel 2 di atas merupakan representasi pola FPm dan FI dalam bahasa Jawa, di mana jika diterapkan ke dalam bahasa Indonesia akan memiliki perbedaan. Perbedaan tersebut tidak jauh menyimpang, mengingat konsep kalimat dalam BJ hampir sama dengan BI, hanya pada frasafrasa pembentuk tertentu yang memiliki perbedaan. Perbedaan penerapan X-Bar dalam setiap bahasa bukan mengarah pada struktur perbedaan frasa secara general, akan tetapi perbedaan tersebut hanya mengacu pada bentuk frasa dan peran frasa yang menduduki inti leksikal suatu kalimat. Konsep yang ditekankan dalam penelitian X-Bar pada dasarnya merujuk pada pola dasar terkait proyeksi X-Bar seperti yang dikemukakan oleh (Mulyadi, 2010) yaitu adanya proyeksi yang lebih tinggi dan proyeksi X-Bar maksimal. 
Berdasarkan sifatnya, interogatif parsial ini berada pada jenis interogatif menanyakan unsur, alasan, dan pendapat. Sifat interogatif parsial berdasarkan distribusi pada Tabel 2 memiliki bentuk yang abstrak. Artinya, pada pola khusus bisa menggunakan pola FPm ataupun FI, bergantung pada letak kata ganti tanya kalimat tersebut. Secara holistik, interogatif parsial dan interogatif total berkontribusi berbeda pada tataran bahasa tulis dengan bahasa lisan dalam komunikasi secara langsung. Model interogatif dalam penelitian ini mengarah pada bentuk bahasa lisan yang terjadi dalam komunikasi secara langsung, artinya secara struktural banyak menimbulkan variasi yang konkret dengan konteks yang berbeda. Sejalan dengan pernyataan (Morley, 2004; Muller, 2018) yang menegaskan bahwa teori X-Bar dapat digunakan pada tataran kalimat yang memiliki struktur pembentuk frasa maupun klausa yang cukup. Analisis kalimat interogatif pada film "Tilik" dalam penelitian ini merupakan representasi analisis X-Bar pada tataran kalimat, di mana unsur-unsur pembentuknya terdiri dari frasa. Analisis XBar pada uraian di atas memberikan gambaran bahwa, konteks yang digunakan dalam interogatif lisan memengaruhi bentuk struktur interogatifnya, baik secara parsial maupun secara total.

Berbeda dengan penelitian Budiman \& Mulyadi (2020) yang menguraikan analisis X-Bar pada fenomena bahasa tulis yang bersumber dari buku bacaan. Penelitian ini memberikan gambaran lain mengenai analisis X-Bar pada tataran bahasa lisan yang digunakan secara langsung oleh penutur dengan mitra tutur dalam film "Tilik". Adegan dalam film "Tilik" yang memuat beberapa bentuk kebahasaan, secara keseluruhan tidak terpaku pada bentuk formal, artinya peletakan kata tanya tidak selalu berada di depan dan adanya penggunaan interjeksi bahasa Jawa seperti lho dan ya. Struktur interogatif pada bahasa lisan sangat berbeda dengan bahasa tulis, hal ini dipengaruhi oleh letak kata tanya dan frasa pembentuk dalam kalimat. Pujiono (20I4) menyatakan bahwa frasa pembentuk suatu klausa dapat dilihat dari FN yang mengisi setiap satuan klausa. Hal ini cukup berbeda dengan hasil temuan dalam penelitian ini, di mana frasa pembentuk dalam tataran kalimat interogatif tidak mengacu pada FN sebagai dasar utama. Akan tetapi frasa pembentuk yang menjadi dasar struktur kalimat mengacu pada FPm dan FI. Setiap bentuk kalimat dengan FPm dan FI dapat diisi dengan FN, FV, Fadj, Fadv, dan FP.

\section{SIMPULAN}

Berdasarkan analisis yang telah dipaparkan sebelumnya, introgatif ya-tidak dan interogatif penyungguhan memiliki sifat total dengan pola mutlak FI. Artinya, bentuk interogatif yang bersifat total dapat berdistribusi dengan pola FI tanpa adanya turunan dari FPm. Sementara itu, jenis interogatif meminta jawaban mengenai suatu unsur, interogatif alasan, dan interogatif pendapat merupakan bentuk interogatif yang bersifat parsial dengan berdistribusi pada pola FPm maupun FI. Secara mutlak interogatif meminta pendapat berada pada pola FPm dengan ciri FPm Spesifier FP berada di awal kalimat. Variasi struktur tersebut didasarkan pada komunikasi lisan sehari-hari yang cenderung tidak menggunakan struktur formal. Adegan dalam film "Tilik" yang memuat beberapa bentuk kebahasaan, secara keseluruhan tidak terpaku pada bentuk formal, artinya peletakan kata tanya tidak selalu berada di depan dan terdapat bentuk interjeksi bahasa Jawa seperti Iho dan ya. Melalui analisis X-Bar, perbedaan struktur dapat memengaruhi peran frasa dalam sebuah kalimat, bergantung pada tata urut setiap frasa.

Penelitian ini hanya membahas sebagian kecil dari jenis-jenis kalimat berdasarkan isinya dan masih perlu dikaji lebih dalam lagi. Penelitian-penelitian selanjutnya diharapkan dapat mengaji lebih jauh mengenai struktur kalimat pada jenis-jenis kalimat lain. Selain itu, penelitian mengenai struktur kalimat bahasa daerah lain perlu dilakukan mengingat Indonesia memiliki beragam bahasa daerah. Penelitian ini diharapkan mampu memberi kontribusi pada khazanah ilmu sintaksis serta studi bahasa Jawa. Selain itu, penelitian ini diharapkan dapat menjadi referensi atau acuan untuk penelitian yang akan datang dan menambah wawasan bagi para pembaca maupun pembelajar bahasa Jawa. 


\section{UCAPAN TERIMAKASIH}

Peneliti mendedikasikan penelitian ini kepada forum peneliti di Program Studi S2 Ilmu Linguistik, Fakultas Ilmu Budaya, Universitas Sebelas Maret Surakarta yang telah mendukung dan berkontribusi dalam menyelesaikan penelitian ini. Selanjutnya, peneliti juga mengucapkan terima kasih kepada semua pihak di bidang peminatan Linguistik Deskriptif FIB UNS yang mendukung terlaksananya penelitian ini dengan baik.

\section{DAFTAR PUSTAKA}

Al-Qumairi, S., Taha, M., \& Arifin, A. (2020). The syntax of possessive-də in Mehri. Lingua, 244, II4. https://doi.org/I0.I016/j.lingua.2020.102910

Astuti, S. P. (2017). Analisis fungsi sintaksis kata apa dan mana dalam bahasa Indonesia. Nusa: Jurnal Ilmu Bahasa dan Sastra, I2(4), 206-215. https://doi.org/I0.I47I0/nusa.I2.4.206-2I5

Brown, K., \& Miller, J. (20I5). Syntax: A linguistic introduction to sentence structure (second edition). Routledge: Sage.

Budiman, J., \& Mulyadi, M. (2020). Konstruksi interogatif bahasa Jepang: Analisis X-Bar. Chi'e: Journal of Japanese Learning and Teaching, 8 (I), 33-42. https://doi.org/I0.15294/chie.v8i1.37327

Caarnie, A. (202I). Syntax: A generative introduction fourth edition. London: Wiley Blackwell.

Caesar, R. O. (2016). An analysis of interrogative constructions in Dangme. Journal of Literature, Language and Linguistics, 21, 35-49.

Chaer, A. (2015). Sintaksis bahasa Indonesia: Pendekatan proses. Yogyakarta: Rineka Cipta.

Cox, R. (2020). Bromberger on the syntax of why-interrogatives. Lingua, 247, I-25. https://doi.org/I0.IOI6/j.lingua.2020.102884

Crystal, D. (2017). English as a global language. Cambrdige: Cambridge University Press.

Eriyanti, R. W. (2017). Koherensi pertanyaan guru pada pembelajaran. KEMBARA: Jurnal Keilmuan Bahasa, Sastra, dan Pengajarannya (e-Journal), 2(I), 77-89. https://doi.org/I0.22219/kembara.vol2.nol.77-89

Fitriyani, D. Z., \& Mulyadi. (2017). Interrogative sentence in Minangkabau language: X-Bar theory. RETORIKA: Jurnal Ilmu Bahasa, 3(I), I88-200. https:/ / doi.org/I0.22225/jr.3.I.229.I88200

Gallego, A. J., \& Martin, R. (2018). Language, syntax, and natural sciences. Cambridge: Cambridge University Press.

Gapur, A. (2018). Konstruksi interogatif polar dalam bahasa Jepang. Ranah: Jurnal Kajian Bahasa, 7I), I-I5. https://doi.org/I0.26499/rnh.v7iI.477

Haegeman. (2006). Introduction to goverment and binding theory. London: Basil Blackwell.

Harahap, R., \& Mulyadi, M. (2018). Kata Tanya dalam konstruksi interogatif bahasa Mandailing. School Education Journal PGSD FIP Unimed, 8(I), 56-65. https:// doi.org/10.24I I4/sejpgsd.v8iI.9778

Isnaini, M. (20I5). Struktur kalimat tunggal dalam karangan bahasa Indonesia Mahasiswa asing tingkat pemula di BIPA UMM. Kembara: Jurnal Keilmuan Bahasa, Sastra, dan Pengajarannya (eJournal), 4, 43-53. https://doi.org/I0.22219/kembara.vIiI.2330

Kebbe, M. (2000). A Transformational grammar of modern literary Arabic. Routledge: Sage.

Lindawati. (2017). Indonesian interrogative sentences: a study of forms and functions. Jurnal Humaniora, 28(3), 348-357. https://doi.org/I0.22I46/jh.v28i3.22289

Lohmann, A., \& Conwell, E. (2020). Phonetic effects of grammatical category: How category-specific prosodic phrasing and lexical frequency impact the duration of nouns and verbs. Journal of Phonetics, 78, I-22. https://doi.org/I0.1016/j.wocn.2019.100939

Mayasari, M., \& Mulyadi, M. (2020). Question words in the interrogative construction in Javanese: in X-Bar theory. Language Literacy: Journal of Linguistics, Literature, and Language Teaching, 
4(I), I45-I52. https://doi.org/I0.30743/11.v4iI.22I7

Morley, G. (2004). Explorations in functional syntax: A new framework for lexicogrammatical analysis. New York: Equinox.

Muller, S. (2018). Grammatical theory: From transformational grammar to constraint-based approaches. New York: Language Science Press.

Mulyadi, M. (2010). Frase preposisi bahasa Indonesia: Analisis X Bar. Kajian Sastra, 34(I), I-I2. Retrived from https:// ejournal.undip.ac.id/index.php/kajiansastra/article/view/267I

Mulyono. (20II). Morfologi bahasa Jawa (bentuk dan struktur bahasa Jawa). Yogyakarta: Kanwa Publisher.

Nikmah, K. (2020). Interrogative sentence: A contrastive study of Arabic and Indonesian. Izdihar: Journal of Arabic Language Teaching, Linguistics, and Literature, 2(3), I83-200. https://doi.org/I0.22219/jiz.v2i3.I0I48

Pandean, M. L. M. (2018). Kalimat tanya dalam bahasa Indonesia. Kajian Linguistik, 5(3), 75-88. https://doi.org/I0.35796/kaling.5.3.2018.25030

Prihatini, A. (2019). Perpindahan frasa nomina benefactive ke argument-positio $\mathrm{N}$ dalam kalimat pasif bitransitif pada. Kembara: Jurnal Keilmuan Bahasa, Sastra, dan Pengajarannya (e-Journal), 4(2), I28-I40. Retrived from https:// ejournal.umm.ac.id/index.php/kembara/article/view/7045

Pujiono. (20I4). Analisis frase nominal bahasa Jepang berdasarkan teori X-Bar (suatu kajian sintaksis). Kotoba, 2, I-22. Retrived from https:/ / ejournal.unand.ac.id/node/82

Radford, A. (2000). Tranformational grammar: A first course. Cambridge: Cambridge University Press.

Santosa, R. (2017). Metode penelitian kualitatif kebahasaan. Surakarta: UNS Press.

Sawirman. (2007). Teori X-Bar pada tataran kata (sebuah resensi buku lieber). Linguistika Kultura, $I(2), \quad$ I93-200. Retrived from https:// jurnalvivid.fib.unand.ac.id/index.php/lingkul/article/view/65/74

Siemund, P. (2017). Interrogative clauses in English and the social economics of questions. Journal of Pragmatics, II9, 15-32. https://doi.org/I0.1016/j.pragma.2017.07.010

Sudaryanto. (2018). Metode dan aneka teknik analisis bahasa: Pengantar Penelitian wahana kebudayaan secara linguistis. Jakarta: Sanata Dharma University Press.

Wahyuni, T. (2000). Sintaksis bahasa Indonesia: Pendekatan kontekstual. Yogyakarta: Lakeisha.

Zahra, S. T., \& Mulyadi, M. (2019). Kalimat tanya dalam bahasa Mandailing: Teori X-Bar. Retorika: Jurnal Bahasa, Sastra, dan Pengajarannya, I2(2), 235-242. https://doi.org/I0.26858/retorika.vI2i2.93I5 